TEME, г. XLIV, бр. 1, јануар - март 2020, стр. 231-249

\begin{tabular}{lr}
\hline \hline Прегледни рад & https://doi.org/10.22190/TEME180410018Z \\
Примљено: 10. 4. 2018. & UDK 159.922.6/.7 \\
Ревидирана верзија: 5. 11. 2019. & $316.356: 37.014$ \\
Одобрено за штампу: 20. 2. 2020. &
\end{tabular}

\title{
СПРЕМНОСТ ДЕТЕТА ЗА ШКОЛУ: ЗНАЧАЈ СПРЕМНОСТИ И ИНТЕРАКЦИЈЕ МИКРОСИСТЕМСКИХ РАЗВОЈНИХ ОКРУЖЕЊА ${ }^{a}$
}

\author{
Слађана Зуковић ${ }^{1 *}$, Кристина Крстић $^{2}$ \\ ${ }^{1}$ Универзитет у Новом Саду, Филозофски факултет, Нови Сад, Србија \\ ${ }^{2}$ Академија струковних студија Шабац, Шабац, Србија \\ sladjana.zukovic@ff.uns.ac.rs
}

\begin{abstract}
Апстракт
Полазак у основну школу значајан је корак на образовној лествици сваког детета, а резултат адекватне спремности за школу очитује се кроз дететов осећај припадности школској заједници и мотивације за остваривање школског успеха. С обзиром на различите индивидуалне карактеристике сваког детета, с једне стране, и на нова и другачија искуства која доноси полазак у школу, с друге стране, намеће се потреба преиспитивања фактора који обликују спремност детета за школу. Полазећи од кратког осврта на приступе који сагледавају феномен спремности за школу, основу рада чини интеракционистички приступ који, поред значаја индивидуалних карактеристика детета, наглашава и значај услова микросистемских развојних окружења у којима дете обитава, те важност њиховог синергијског деловања. У том смислу, а водећи се савременом конструкцијом појма „спремности за школу”, фокус рада стављен је на сагледавање обележја породичног и институционалног (предшколског и школског) контекста, као и контекста заједнице, те на могућности удруженог деловања развојних окружења кроз примере добре праксе у нашем образовном контексту. Закључује се да, иако сваки од поменутих микросистемских окружења појединачно доприносе дететовој спремности за школу, најбољи ефекти се постижу кроз њихову интеракцију која доводи до континуитета утицаја и максималног остварења дететових потенцијала у новом образовном окружењу.
\end{abstract}

Кључне речи: спремност за школу, дете, породица, институције организованог васпитања и образовања, заједница.

\footnotetext{
${ }^{a}$ Рад је настао у оквиру пројеката Квалитет образовног система Србије у европској перспективи (179010) и Педагошки плурализам као основа стратегије образовања (179036), које финансира Министарство просвете, науке и технолошког развоја Републике Србије.
} 


\title{
CHILDREN'S SCHOOL READINESS: THE IMPORTANCE OF READINESS AND THE INTERACTION IN THE MICROSYSTEMS OF THE DEVELOPMENT ENVIRONMENTS
}

\begin{abstract}
Starting elementary school is an important step on the education ladder of every child, and the result of adequate school readiness is reflected in the child's feeling of belonging to the school community and the motivation for accomplishing school success. Bearing in mind, on the one hand, different individual characteristics of every child, and, on the other, new and different experiences when starting school, there is a tendency to reexamine the factors shaping (and influencing) the child's readiness for school. Starting from a brief retrospect of the approaches that review the phenomenon of school readiness, the essence of this paper consists of an interactive approach which, beside the importance of individual children's characteristics, also emphasizes the significance of conditions in the microsystem of the development environments in which the child spends their time, as well as their synergistic actions. In this manner, while following the contemporary construction of the term "school readiness," the focus of this paper is set on the review of the hallmarks in family and institution (pre-school and school) context, as well as in the community context, and the possibility of a joint action of the development environments through examples of good practice in our educational context. Although each of these mentioned microsystem environments individually contributes to children's school readiness, it can be concluded that the best effects are accomplished through their interaction which leads to the continuity of influence and the maximum of reaching children's potentials in new education environment.
\end{abstract}

Key words: school readiness, child, family, institutions of organized education, community.

УВОД

Поласком у школу започиње нова етапа у развоју детета, при чему нова улога детета као ученика првог разреда носи са собом широк дијапазон различитих промена и захтева у сваком погледу. Поседовање појединих академских способности, праћење упутстава од стране одраслих, добро успостављени вршњачки односи, испољавање позитивних емоција - представљају неке од индикатора спремности детета за школу. Међутим, чињеница да нису сва деца подједнако и адекватно припремљена за ново образовно, тј. школско, окружење намеће потребу за континуираним преиспитивањем фактора који обликују спремност детета за школу, а што уједно актуализује и питање конструкције и тумачења самог појма „спремност за школу”.

Прегледом литературе (Čudina-Obradović, 2008; Dockett \& Perry, 2007; High, 2008; Klemenović, 2014; Meisels, 1998) могуће je уочити да тумачење термина „спремност за школу” има корене у различитим теоријским концепцијама, на основу којих су развијени приступи у његовом појмовном одређењу. Нативистичко-идеали- 
стички приступ, ослањајући се на теорију матурациониста, наглашава утицај биологије на спремност за школу, при чему се развој детета посматра у светлу деловања унутрашњег сата који оно поседује. Дакле, критеријум који одређује дететову подобност да похађа школу јесте његов узраст. С друге стране, срединско-емпиристички приcmyn спремност за школу посматра кроз спољашње доказе учења, попут познавања боја, облика, бројева, слова, при чему до изражаја долази значај непосредне укључености одраслих из породице или вртића, као и важност уношења школског садржаја у предшколско учење. За разлику од поменутих идеја нативиста и емпириста, сощиоконструктивистички приступ помера фокус са процене детета на заједницу у којој дете живи. Овај приступ спремност за школу сагледава као уграђену унутар социјалног и културног миљеа детета, односно као стварање низа идеја или значења насталих током учешћа детета у различитим развојним окружењима. Међутим, спремност за школу се у овом случају везује за одређени контекст и има значење само у том контексту.

Још свеобухватније гледиште спремности за школу нуди интеракиионистички приступ, који представља интеграцију елемената претходно описана три приступа, те наглашава значај интеграције вештина које деца са собом понесу у школу и искуства изван, пре и током школе. У том оквиру изведена је радна дефиниција спремности за школу која укључује три компоненте: спремност деце за шко$л y$ - одражава могућност да деца учествују у учионици и стичу искуства која се односе на учење; спремност школе за деиу - подразумева реакцију школе на уписану децу; подршка породице, заједнице $u$ релевантних служби - подразумева промовисање породичног и окружења заједнице у подршци учењу (Dockett \& Perry, 2007; Rhode Island KIDS COUNT, 2005; UNICEF, 2012).

Дакле, спремност за школу треба посматрати као вишеструк конструкт (Büyüktaşkapu Soydan, 2017; Nissksaya, 2018; Woodhead $\&$ Moss, 2007), односно као мултидимензионални феномен који подразумева једнаке напоре и заједничку одговорност како деце тако и одраслих у породицама и установама у заједници, те захтева спремност и удружено деловање микросистемских развојних окружења. У складу са оваквим становиштем, у даљем тексту ће, поред осврта на домене дететовог развоја, акценат бити стављен на домене спремности породице, предшколске установе/школе и заједнице као димензије које су од кључног значаја за пружање адекватних стимулуса за развој детета у целини, а самим тим за његов полазак у школу. 


\section{ДОМЕНИ ДЕТЕТОВЕ СПРЕМНОСТИ ЗА ШКОЛСКО ОКРУЖЕЬЕ}

Раније дефиниције спремности за школу углавном су указивале на важност развијености одређених когнитивних способности, при чему је посебан акценат стављан на спремност детета да научи да чита (Arnold, Bartlett, Gowani \& Merali, 2007; Shore, 1998). Уместо тога, савремено гледиште „спремност за школу” посматра као „скуп квалитета, услова и карактеристика који, ако су у интеракцији, деци омогућавају да искористе своје могућности и одговоре на школске захтеве" (Pianta, 2002, р. 4). Стога се у релевантној литератури (Arnold et al., 2007; High, 2008; Kagan \& Rigby, 2003; Rhode Island KIDS COUNT, 2005; Shore, 1998; Wynn, 2002) указује на то да спремност за школу обухвата пет међусобно повезаних области: физички и моторички развој; социјални и емоционални развој; приступ учењу; развој комуникацијских вештина и писмености; когнитивни развој и општа знања. Сваки од ових пет домена дечјег развоја, наизглед различитих, али међусобно повезаних, имају своје битне одреднице.

Домен који се односи на физички и моторички развој (с обзиром на то да укључује факторе попут здравственог стања, раста, физичких способности и могућих сметњи у развоју) представља важну компоненту која детету обезбеђује могућност концентрације и потребну енергију за контекст какав је школски. Стога је важно да дете има правилну исхрану, равномерну смену сна, одмора и активности важних за развој фине и крупне моторике. Други домен, који се односи на сочијални и емоционални развој, претпоставља да ће дете које воли да буде у друштву других и које је сигурно у своје способности време у школи проводити са уживањем. Као такав, овај домен садржи два међусобно повезана елемента која утичу на дететово учење и социјално прихватљиво понашање. Социјални развој огледа се у способности детета да оствари интеракцију са другом децом, као и да развије капацитете за саморегулацију, док емоционални развој обухвата дечју перцепцију себе, дететову способност детета да тумачи и изрази своја осећања, као и способност да разуме осећања других. Развоју овог домена доприноси пружање разноврсних искуствених прилика, као што су: обављање свакодневних послова, контакти са вршњацима, ситуације у којима оно треба да следи упутства и буде доследно, задаци који гарантују успех, али који изискују ослањање детета на сопствене способности, уз давање подстицаја и похвала од стране одраслих. Трећи домен спремности за школу је дететов приступ учењу, који се односи на дечју склоност да користи вештине и знања. Начин на који дете прилази учењу веома је важан јер дете које је успешно у школи ужива у учењу, па се као кључни елементи овог домена јављају ентузијазам, радозналост и упорност. 
Потребно је обезбедити детету довољно прилика за истраживање, креативност, решавање проблема и преузимање одговорности. Четврти домен односи се на комуникаиију и писменост. Слушање, говор и вокабулар чине комуникацију, док писменост укључује разумевање штампаних медија, смислених прича, рану писменост и повезивање слова са звуцима. Активности као што су слушање других, причање прича, коришћење различитих средстава за писање, цртање и бојење допринеће развоју комуникације и писмености. Коначно, пети домен односи се на когнитивни развој и општа знања. Овај домен подразумева размишљање и решавање проблема, као и знања о одређеним предметима и начинима на које свет функционише, а укључује математичка знања, апстрактно мишљење и машту. Оно што утиче на развој овог домена јесу пре свега посете различитим местима у заједници или суседству у којима деца искуствено уче, али и доступност различитих књига и материјала (Rhode Island KIDS COUNT, 2005; Wynn, 2002).

Узимајући у обзир важност сваког поменутог домена, јасно је да спремност за школу не треба ограничавати на једну област развоја или функционисања, већ је треба тумачити на холистички начин који укључује међусобни однос вештина и понашања кроз домене развоја и учења (UNICEF, 2012). У складу са тим, савремени концепт спремности за школу истиче да дете као члан различитих друштвених и културних заједница треба да представља активног учесника у обликовању свог идентитета. Притом је веома важно успостављање партнерског односа између породице, васпитно-образовних установа и заједнице, јер такав однос доводи до учвршћивања веза између дететових искустава и учења у различитим окружењима. Још ако су поменута окружења изазовна, захтевају интелектуално ангажовање, пружају осећај сигурности и могућности социјалног прилагођавања, дете ће успешније савладати прелазак из једне у другу средину (Pavlović Breneselović i Krnjaja, 2017).

\section{ПОДРЖАВАЈУЋЕ ПОРОДИЧНО ОКРУЖЕЬЕ КАО ДИМЕНЗИЈА СПРЕМНОСТИ ЗА ШКОЛУ}

Породица као битна димензија конструкта „спремност за школу" представља најважнију средину развоја и учења детета пре него што се оно укључи у формално образовање. То потврђују и резултати истраживања (Şahin, Sak \& Tuncer, 2013), који су показали да већина испитаних васпитача и учитеља наводи породицу као развојно окружење које има круцијалну улогу у процесу припреме детета за школу. Такође, стручњаци сугеришу да је, поред важности сагледавања породичних социо-демографских карактеристика, још важније размотрити дешавања у породици и како та дешавања утичу на уче- 
ње и развој деце (Dockett \& Perry, 2007), те да је битно размотрити начине који би допринели оснаживању родитеља да успешно обављају родитељске улоге и да се активно укључе у процес учења своје деце (Zuković, 2013; 2017).

Током дететовог развоја јављају се разноврсне специфичне акције родитеља које обликују родитељско понашање. Три кључне карактеристике родитељског понашања, које поједини аутори (Edwards, Sheridan \& Knoche, 2008, p. 3) називају родитељским ангажовањем, јесу: 1) топлина и осетљивост; 2) подршка развоју аутономије детета; 3) активно учешће родитеља у учењу. Иако су све три карактеристике веома важне за правилан развој детета и његово успешно сналажење ван кућног окружења, посебно треба издвојити трећу - активно учешће родитеља у учењу, која почиње са рођењем детета, а нарочито долази до изражаја током дететових предшколских година, тј. родитељи тада постају посебно свесни њене важности. Истраживања су показала да подржавајући услови у породичном окружењу и ван њега, организовани на многе директне и индиректне начине од стране родитеља означавају неку врсту „породичног курикулума” (Edwards et al., 2008), те да односи, пракса и обрасци породичног живота који чине променљив „Породични курикулум” представљају снажнији предиктор академског образовања од социо-економског статуса породице (Redding, 1997).

Породични курикулум односи се на праксу породице која укључује следеће компоненте: однос родитељ-дете, рутина породичног живота; родитељска очекивања и надзор (Polovina, 2008; Redding, 1997). Прва компонента однос родитељ-дете остварује се кроз: родитељско изражавање наклоности према детету; разговоре о догађајима у свакодневици; заједничке дискусије о прочитаном или одгледаном садржају (књиге, часописи, телевизијски или интернет садржаји); породичне посете различитим институцијама локалне заједнице (библиотека, музеј, зоолошки врт); пружање подстицаја детету у коришћењу нових речи и проширивању свог вокабулара. Рутина $y$ породичном животу као друга компонента породичне праксе, односи се на: време за учење у породичном дому; време за рутинске активности на дневном плану (јело, сан, игра, рад, учење и читање); кутак за учење и читање; породично интересовање за активности образовног карактера, али и хобије, те игре. На овај начин детету се постављају јасне границе, подстиче се продуктивно коришћење времена и обезбеђује искуствено учење, што доводи до дечјег успеха у школи. Трећа компонента подразумева стављање нагласка на домаће задатке, што се остварује кроз родитељски надзор дететових активности у слободном времену (гледање телевизије, дружење са вршњацима) и родитељска очекивањ $а$ у погледу максималног остваривања дететових потенцијала, остваривања успеха у школи, те целокупног раста и развоја. 
Све наведене компоненте породичног курикулума, сагледане кроз адекватну интеракцију, стимулацију и подршку од стране родитеља - обезбеђују услове да дете буде спремно за захтеве школског контекста и да оствари што боље резултате у учењу. Другим речима, градивни блокови социјалног и емоционалног односа који су потребни за дететов успех у школи у значајној мери су зависни од подршке и односа прихватања унутар породичног контекста (Britto \& Limlingan, 2012).

Стога, имајући у виду пре свега „моћ језика прихватања” (Gordon, 2003) у породичном контексту, димензија „спремне породице” у оквиру концепта спремности детета за школу подразумева стварање подстицајног породичног окружења и максималног родитељског ангажовања у осмишљавању свакодневних активности које ће припремити дете за успешно функционисање у школском окружењу. Значајан ресурс у том смислу могу бити развојно-превентивни програми подршке родитељима и породицама (посебно породицама у ризику) - (Zuković, 2017), било да је реч о програмима чији су носиоци васпитно-образовне институције, или да је реч о шире димензионираним програмима на нивоу заједнице.

\section{КАПАЦИТЕТИ ИНСТИТУЦИЈА ОРГАНИЗОВАНОГ ВАСПИТАҢА И ОБРАЗОВАЬА КАО ДИМЕНЗИЈА СПРЕМНОСТИ ЗА ШКОЛУ}

Другу веома важну карику дететове спремности за школу представља деловање предшколске установе и школе као институција организованог васпитања и образовања.

У контексту предшколске установе деца уче и стичу искуства на различите начине, при чему су од велике важности активности, представљени материјали, интеракција са вршњацима, понашање васпитача (Goble et al., 2016). Појављивање и смењивање различитих програмских модела присутно је у готово свакој културној и педагошкој традицији земаља које организују институционалне програме предшколског васпитања и образовања. Међутим, оно што доминантно спецификује одређени програм предшколског васпитања и образовања, као и његов допринос целокупном дечјем развоју - јесу активности којима су деца заокупљена и ниво ангажованости које оне омогућавају. Тако су у пракси присутни предшколски програми који полазе од детета и који укључују самодетерминишуће активности, спонтано истраживање и игру (Модел А), односно предшколски програми који се заснивају на активностима које су унапред припремили и осмислили одрасли (Модел Б) - (Klemenović, 2009).

С обзиром на значај оба модела, заступљена су стална преиспитивања истраживача који од њих има веће ефекте на дечју спремност за школу. Резултати студије (Chien et al., 2010, према: Goble et al., 
2016) указују на то да је за развој академских вештина деце ефикасније време проведено у контексту у којем је одрасли носилац активности. Међутим, поред значајног увида у то који је контекст најважнији за промовисање дечјих академских вештина, поменута студија се у том случају ограничава само на академски домен школске спремности. Друга студија (Burchinal et al., 2008, према: Klemenović, 2014) установила је пак умерен позитиван утицај предшколских курикулума заснованих на инструкцијима васпитача који као модел понашања утиче на развој академских и неакадемских вештина деце (коришћење језика, употреба различитих стратегија мишљења, развој сарадничких односа, комуникација са другима), с обзиром на то да је заступљена позитивна дисциплина и јасна повратна информација. С друге стране, резултати неких истраживања (Hirsh-Pasek \& Golinkoff, 2011, према: Goble et al., 2016) предочили су да је развој социјалних вештина и опхођење детета према школи позитивно повезано са временом проведеним у контексту у којем активностима управљају деца. Нека истраживања (Nissksaya, 2018) показала су да традиционални приступ (у којем дете претежно заузима позицију објекта васпитнообразовног процеса) доприноси развоју вишег нивоа вербално-логичког расуђивања код деце, док развојни приступ (који полази од индивидуалних карактеристика деце) доводи до бољих исхода у погледу дечје иницијативе и успостављања равноправнијег односа између васпитача и детета. У светлу наведених разлика, значајно је указати на становиште да наведене активности и приступи не треба да представљају две стране једног континуума, већ да истовремено делују у пракси где се препознаје заједничка акција учесника (Graue, Clements, Reynolds \& Niles, 2004), те да се предшколски курикулум заснива на комбинацији садржаја и активности иницираним како од стране деце тако и од стране васпитача (Taguma, Litjens \& Makowiecki, 2013).

До недавно се и у нашој земљи, у години пред полазак у школу, остваривао Припремни предшколски програм Модела А и Модела Б, којим се настојао успоставити континуитет са основношколским програмом (Pravilnik o opštim osnovama predškolskog programa, 2006), те су и код нас међу истраживачима и међу практичарима често биле присутне дилеме у погледу ефеката ових модела. На темељу таквих дилема, а подстакнуто примерима добре праксе у Србији и свету, као и потребом усклађивања стратешких и законских докумената са општим друштвеним променама и савременим теоријским поставкама о раном развоју и учењу, настале су нове концепције Основа програма - Године узлета (Pravilnik o osnovama programa predškolskog vaspitanja i obrazovanja, 2018). Тиме је направљен значајан помак и у погледу унапређења активности које би могле допринети дететовој спремности за школу, с обзиром на то да се програм манифестује кроз односе које дете гради са вршњацима и одра- 
слима, као и кроз интегрисано учење у којем делање детета обухвата игру, активно учешће у животно практичним ситуацијама и ситуацијама планираног учења.

Када је реч о школском контексту, крајем прошлог века постаје актуелна тзв. транзициона тематика, која пажњу помера са детета које је спремно за школу ка преиспитивању школских обележја и различитих облика рада који доприносе да се и школа прилагоди деци (Klemenović, 2014), што подразумева и осмишљавање транзиционих програма који олакшавају прелаз детета из предшколског у школско окружење (Krstić i Zuković, 2017). Као такви, транзициони програми имају за циљ премошћавање јаза и стварање партнерског односа између породице, предшколске установе и школе. Иако могу варирати од школе до школе, од заједнице до заједнице, чињеница је да њихов квалитет и ефикасност у великој мери зависи од комуникације и сарадње свих који су укључени у процес (Margetts, 2003). У вези са тим јавља се потреба утврђивања капацитета школе да се мења у смеру побољшања услова и прилика за свако дете. Тумачећи капацитет за промене, неки аутори (Stoll, 1999, према: Oterkiil \& Ertesvåg, 2012) указују на то да организација сама по себи не може бити „спремна”, већ је реч о динамичном процесу сталног раста и развоја. Такође, капацитет за промене, поред појединачних чланова организације, укључује и организацију у целини. Како ће људи деловати и какве ће односе успостављати у пракси деловања умногоме зависи од педагошког менаџмента и културе педагошке организације (Zuković \& Knežević-Florić, 2014), односно од утицаја подземне реке осећања, обичаја, норми и вредности која тече испод површине свакодневних активности у школи (Peterson \& Deal, 2002, према: Pavlović Breneselović, 2015).

У том смислу, група за ресурсе спремне школе водила је дискусију о факторима који карактеришу ефикасност школе и на основу тога идентификовала је десет кључних принципа спремних школа (Shore, 1998). Наиме, спремне школе: 1) обезбеђују услове за адекватну адаптацију на школско окружење; 2) теже континуитету између породице, предшколске установе и основне школе; 3) помажу деци да развију осећај припадности школском окружењу; 4) посвећене су успеху сваког детета; 5) посвећене су успеху сваког наставника и сваког одраслог који ступа у интеракцију са децом током школског дана; 6) уводе или проширују приступе који су показали да доводе до повећања школског постигнућа; 7) теже да мењају праксу и програме у случају да они немају користи за децу; 8) заступају дечје интересе у широј заједници; 9) преузимају одговорност за образовна постигнућа; 10) имају јако вођство (Shore, 1998, p. 8).

Укратко речено, спремност школе огледа се у њеној осетљивости на потребе сваког детета, у препознавању важности породичног 
и предшколског искуства за успех у школском учењу, као и у пружању могућности укључивања свих актера ради лакше адаптације детета у новом окружењу.

\section{РЕСУРСИ И ПОТЕНЦИЈАЛИ ЗАЈЕДНИЦЕ КАО ДИМЕНЗИЈА СПРЕМНОСТИ ЗА ШКОЛУ}

Дететову и родитељску компетентност могу нарушавати или пак јачати различити посредни и непосредни утицаји из околине окарактерисани као обележја заједнице у којој породица егзистира (Garbarino et al., 2005, према: Pećnik, 2013). Чињеница је да постојање протективних фактора у заједници утиче на добробит њених чланова. Стога, расположивост заједнице различитим физичким, институционалним и социјалним ресурсима може битно допринети дететовој спремности за школу (Zaslow, Calkins, Halle, Zaff \& Margie, 2000). Пружаоци услуга могу бити различите институције, организације, удружења на челу са њиховим представницима. С тим у вези, поједини аутори (Ferić, 2015; Nenadić-Bilan, 2015) услуге и програме подршке деци и породицама у заједници класификују на формалне и неформалне системе, док неки аутори (Pećnik, 2013) препознају и деловање полуформалних система подршке.

Формални систем подршке односи се на деловање јавног сектора, који, поред рада васпитнообразовних институција, подразумева и рад здравства, центра за социјални рад и судства. Здравство пружа услуге деци и њиховим породицама кроз превентивну (саветовалишта), примарну (домови здравља и здравствени центри) и секундарну (болнице) здравствену заштиту, док су центар за социјални рад, домови и установе за смештај деце задужени за дечју социјалну заштиту. Деловање судства подразумева улогу полиције и органа правосуђа у заштити деце од злостављања и занемаривања (WEBIN, 2015).

Неформални систем подршке чине шира породица, пријатељи, суседи и познаници. Чланове повезује природна заједничка повезаност, односно сродство и суседство, па се ради о природној социјалној мрежи подршке, у којој су заступљене активности попут разговоpa, посета, дружења, помоћи и неформалног деловања (Ferić, 2015; Nenadić-Bilan, 2015). Искуства обликована кроз овај вид интеракције важна су за сву децу, а посебно за децу из породица са лошим социоекономским статусом, нижим нивоом образовања родитеља, као и за децу из једнородитељских породица. У том случају, суседи се могу ставити у позицију додатних узора, ментора, старешина и супервизора деци која су део суседства (Zaslow et al., 2000). Осим доступности наведених људских ресурса, важна је и уређеност јавних површина као ресурса који поседују значајан потенцијал за јачање породичних и ванпородичних односа. Игралишта, рекреативни објекти и паркови 
само су неки од јавних простора који представљају јединствени „дом на отвореном", чији су капацитети значајни и за децу и за одрасле. Поред унапређивања породичног дружења, међугенерацијске солидарности и међуљудских односа у заједници, значајан је и приступ утемељен на стимулишућим материјалима, те стварање различитих прилика за учење и игру намењених деци раног и предшколског узраста (UNICEF, 2014; Zaslow et al., 2000).

Полуформална подршка подразумева организовану мрежу грађана, у овом случају родитеља, деце и породица у заједници (Pećnik, 2013). Реч је о мрежи која се ствара ради задовољења потреба и решавања проблема грађана у случајевима када одређене институције и власти из различитих разлога (непостојање средстава, немање надлежности, застарели начини и приступи у решавању проблема и сл.) нису у могућности да на адекватан начин реагују (Radojičić i Rašković, 2006).

Дакле, спремну заједницу, као што истичу стручњаци (Kagan \& Rigby, 2003), треба да одликује доступност институционалних ресурса, обезбеђивање сигурног и подржавајућег локалног окружења, као и координирано одлучивање о реализацији различитих програма подршке за децу и њихове породице.

\section{КА УДРУЖЕНОМ ДЕЛОВАЬУ РАЗВОЈНИХ ОКРУЖЕЬА - ОД ТЕОРИЈСКИХ ЗАМИСЛИ ДО ПРАКТИЧНИХ РЕШЕЬА}

Водећи се интеракционистичким гледиштем појма „спремност за школу”, значајно је осврнути се на потребу удруженог деловања развојних окружења, односно на могућности имплементације овако теоријски утемељеног конструкта у праксу нашег васпитнообразовног контекста. Полазну основу, свакако, чини законски оквир на основу којег се доносе бројна стратешка документа и креирају релевантни програми васпитнообразовног рада у институцијама. Тако се, на пример, на основу члана 7 Закона о основама система образовағьа и васпитања (2017), у остваривању општих принципа образовања и васпитања, између осталог, посебна пажња посвећује сарадњи са породицом, локалном заједницом и широм друштвеном средином, те наглашава значај подршке преласку детета у следећи ниво школовања и остваривању континуитета у образовању и васпитању. Међутим, поставља се питање у којој мери предшколски и школски програми који произлазе из законског оквира заиста одражавају повезаност и удружено деловање свих укључених у васпитнообразовни процес, остварујући тиме континуитет и утицај на спремност детета.

Као прилог разматрању поменутог питања значајно је навести студију Krnjaja i Pavlović Breneselović, 2013, у оквиру које је вршена анализа Општих основа програма на којима је дуги низ година почи- 
вао васпитнообразовни рад у нашим предшколским установама. Анализа је показала да је кроз улоге васпитача у Моделу А припремног предшколског програма било речи о планирању сарадње са породицом и друштвеном средином, али да улоге нису биле доследно приказане у сегментима програма који се тичу аспеката развоја. Слично је и са схватањем односа у моделу Б припремног предшколског програма, где је акценат стављан на социјалну готовост за полазак у школу и на садржаје у домену области упознавања друштвене средине. Поред тога, дете се сагледавало као одговорно за спремност за школу, уместо да се тежиште стављало на однос и заједничку спремност институција и заједнице у циљу обезбеђивања услова за образовање детета.

Овакво стање имплицира потребу вођења рачуна о дискурзивном значењу самог текста програма, јер програм (посматран као вредносни оквир који одређује оно у шта верујемо и чему тежимо по питању васпитања и образовања, улоге детета, одраслих и заједнице) помаже да носеће идеје и вредности постану уврежене културне норме свих учесника праксе и на тај начин трансформише систем (Pavlović Breneselović, 2015). Такође, имајући у виду реална дешавања у друштву и актуелне вредности које се одражавају на промене у образовном систему, неопходно је и да предшколски и школски програми буду сагледани кроз призму социјалног контекста у којем се обликују (Krstić, 2017). У складу са тим, питање диверзификације је од кључног значаja, посебно ако се има у виду да диверзификација доноси промене у схватању образовања као механизма културне продукције. У том оквиру, систем васпитања и образовања треба да поприми карактеристике отворености, аутентичности и демократичности, те да постане заједница деце и одраслих чије се активности заснивају на размени, дијалогу, заједничким истраживањима и делању (Miškeljin, 2014). Овакав приступ подразумева уважавање детета као компетентног бића са аутентичним начином изражавања и учења, али и грађење партнерског односа са породицом и широм локалном заједницом.

Иако се чини да се описан приступ у нашем образовном контексту још увек налази на клатну од теоријских замисли до практичних решења, очекује се да ће актуелни реформски подухвати у нашем систему јавног васпитања и образовања омогућити да подршка учењу и развоју деце/ученика заиста буде остварена кроз „заједничко учешће деце и одраслих као аутентичних људских односа и заједништва у ситуацијама, догађајима и активностима које за њих имају смисла" (Правилник о Основама програма предшколског васпитања и образовања, 2018, стр. 9-10). Притом је битно истаћи примере добре праксе који показују користи удруженог деловања развојних окружења. Тако, на пример, пројекат Карика која недостаје - Развијање механизама подршке детету са тешкоћама при 
преласку на следећи ниво обавезног образовања у „редовном образовном систему" (Zlatarović i Mihajlović, 2013) представља модел свеобухватне, систематске, планиране и индивидуалне подршке деци са тешкоћама у развоју које полазе у први, односно пети, разред. Искуства деце, родитеља, стручњака у предшколским установама и основним школама, али и осталих стручних сарадника укључених у овај пројекат - представљају важан ресурс за унапређивање васпитнообразовне праксе у смеру оснаживања свих оних који су део образовног система.

Још један од примера добре праксе у нашој земљи јесте Програм кућних посета породицама у руралној средини (Mihić, Rajić, Mirosavljević, Stojić i Lukovnjak, 2016), с обзиром на то да је подразумевао учешће професионалаца из прешколског окружења (васпитача и стручног сарадника) и школског окружења (учитеља) у локалној заједници. Како су се циљеви односили на адекватно и благовремено информисање родитеља о начину на који ће дизајнирати простор за учење и упућивање родитеља на начине на основу којих ће подржати будућег првака и савладати почетне изазове током транзиционог периода, позитивни исходи програма огледају се у јачању родитељских капацитета и развијању вештина потребних за стварање подржавајуће породичне средине.

Пример добре праксе полуформалне подршке на нивоу заједнице јесте Удружење „Родитељ”. Оснивачи удружења су родитељи који су, вођени личним искуствима, препознали значај системске подршке родитељству у нашој земљи. Чланове овог удружења чине стручњаци из различитих области - психолози, педагози, учитељи, васпитачи, логопеди, дефектолози, здравствени радници, правници и други, чиме се настоји одговорити на широку лепезу изазова које са собом носи родитељство. Поред доступности различитог садржаја, значајан подухват овог удружења јесте пилот-пројекат започет 2012. године. Ради се о Центру за рани развој деце (ЦРР), који има за циљ јачање родитељских компетенција деце предшколског узраста, нарочито деце која нису укључена ни у какав предшколски програм (вртићи, школице и сл.). Родитељи који нису укључени у активности центра имају прилику да своје педагошко образовање као родитеља о дечјем развоју и учењу унапреде путем доступног материјала на веб-сајту.

\footnotetext{
${ }^{1}$ Први огранак Удружења „Родитељ” основан је у Београду, након чега су њихове идеје и визија препознати и у другим градовима у Србији (Нови Сад, Ада, Темерин, Бачка Паланка, Сомбор, Сремска Митровица, Ниш, Пирот, Ужице, Чачак, Крагујевац, Краљево, а у току је и оснивање у још неколико градова), чије је припајање довело до Мреже удружења, која делује од 2006. године до данашњих дана (www.roditelj.org/mreza-roditelj).
} 
Предочени напори теоретичара и практичара у нашем образовном контексту поткрепљују становиште да је за поспешивање школске спремности потребно размотрити могућности развоја дечјих вештина и понашања (Rhode Island KIDS COUNT, 2005), али и континуирано преиспитивати могућности оснаживања капацитета и удруженог деловања микросистемских развојних окружења која у значајној мери обликују дететов развој и понашање.

\section{ЗАКЉУЧАК}

Дискусије усмерене на то да ли деца треба да буду спремна за школу или је пак школа та која треба да буде спремна за децу - доводе до поједностављивања појма спремност за школу. Наиме, реч је о комплексној тематици с обзиром на то да развој и напредак детета изискује посвећеност и пажњу од стране различитих микросистемских окружења. Неспорно је да подржавајуће породично окружење представља један од круцијалних фактора који обликују дететову спремност за школу. Међутим, неспорна је и чињеница да деца и породице не обитавају у некаквом вакууму, издвојено од света који их окружује. Напротив, за успех и напредак детета, поред породице, заслужне су институције организованог васпитања и образовања, као и ужа или шира заједница (Early Childhood Collaboration Network, 2000). Предшколска установа својим програмским садржајима, али и материјалним и организационим капацитетима, у великој мери детерминише развој предшколског детета. С друге стране, савремено схватање спремне школе захтева средину која је отворена, флексибилна, спремна за промене и увођење иновација. Пре свега се мисли на могућност школе да изађе у сусрет потребама сваког детета. Поред тога, како истичу неки аутори (Pavlović Breneselović i Krnjaja, 2017), опште друштвене и економске карактеристике, пракса друштвене бриге о деци и просветна политика једне заједнице обликују услове и начине одрастања детета. У том смислу, питање спремности детета за школу представља заједничку одговорност свих заинтересованих страна у пружању подршке детету да буде припремљено за нову врсту захтева који ће се јавити у школском окружењу (Early Childhood Collaboration Network, 2000; Zuković, 2013).

Дакле, чињеница је да сваки развојни контекст, у складу са својим специфичностима и обележјима, обезбеђивањем адекватних услова и услуга, може допринети развоју деце и њиховој спремности за школу. Међутим, изузетно је важно јачање удруженог деловања кроз координисани рад и интеграцију услуга између различитих микросистемских развојних окружења како би њихови ресурси и капацитети на прави начин били искоришћени, те како би се остварио континуитет утицаја и максималног остварења дететових потенција- 
ла у новом образовном окружењу. Ово је остварљиво уколико родитељи и професионалци имају јасну визију концепта „спремности за школу" (Broström, 2003) и уколико применом приступа коконструкције (Niesel \& Griebel, 2007) међусобно ускладе очекивања, те пронађу начине на које се процеси учења у различитим окружењима могу повезати. Уз све наведено, спремност детета за школу подразумева континуирано развијање компетентности установа, и то у смеру организација које уче и делују у трајном стању промене и где знање настаје на основу укључености и размене свих актера - деце, родитеља, васпитача/наставника, шире заједнице (Slunjski, 2006). На тај начин установе постају места „судара” или, боље речено, „сусрета” компетенција одраслих (значајних других), који су подједнако важни у дететовој припреми за школу.

\section{ЛИТЕРАТУРА}

Arnold, C., Bartlett, K., Gowani, S. \& Merali, R. (2007). Is Everybody Ready? Readiness, Transition and Continuity: Reflections and Moving Forward. Workin Paper 41. Den Haag: Bernard van Leer Foundation.

Britto, P. R. \& Limlingan, M. C. (2012). School Readiness and Transitions. New York: UNICEF.

Broström, S. (2003). Communication and continuity in the transition from kindergarten to school. In H. Fabian \& A. W. Dunlop (Eds.), Transitions in the Early Years: Debating Continuity and Progression for Young Children in Early Education (pp.52-63). London and New York: Taylor \& Francis Group.

Büyüktaşkapu Soydan, S. (2017). Some Variables Predicting the School Readiness of Preschool Children. Journal of Faculty of Educational Sciences, 50(1), 189-208.

Čudina-Obradović, M. (2008). Spremnost za školu: višestrukost značenja pojma i njegova suvremena uporaba [School Readiness: The Multiple Meanings of the Term and its Contemporary use]. Odgojne znanosti, 10(2), 285-300.

Dockett, S. \& Perry, B. (2007). Transitions to School: Perceptions, Expectations, Experiences. Australia: UNSW Press.

Early Childhood Collaboration Network (2000). Continuity in Early Childhood: A Framework for Home, School, and Community Linkages. Tallahassee, FL: U.S. Department of Education, Office of Educational Research and Improvement. Retrieved June 13, 2016 from http://www.serve.org/FileLibraryDetails.aspx?id=82

Edwards, C. P., Sheridan, S. M., \& Knoche, L. (2008). Parent Engagement and School Readiness: Parent-Child Relationships in Early Learning. Faculty Publications, Department of Child, Youth, and Family Studies.

Ferić M. (2015). Razvoj sveobuhvatnog sustava podrške obiteljima: prilike i izazovi [Development of Comprehensive Family Support System: Opportunities and Challenges]. U: Kaljača, S. i M. Nikolić (Ur.): VI međunarodna naučno-stručna konfrenecija Unapređenje kvalitete života djece $i$ mladih (84-94). Tuzla: Udruženje za podršku i kreativni razvoj djece i mladih.

Goble, P., Hanish, L., Martin, C. L., Eggum-Wilkens, N., Foster, S. \& Fabes, R. (2016). Preschool Contexts and Teacher Interactions: Relations with School Readiness. Early Education and Development, 27(5), 623-641. 
Gordon, T. (2003). Umeće roditeljstva: kako podizati odgovornu decu [Parent Effectiveness Training: The Tested New Way to Raise Responsible Children]. Beograd: Kreativni centar.

Graue, E., Clements, M. A., Reynolds, A. J., \& Niles, M. D. (2004). More than teacher directed or child initiated: Preschool curriculum type, parent involvement, and children's outcomes in the child-parent centers. Education Policy Analysis Archives, 12(72), 1-38.

High, P. (2008). School Readiness. American Academy of Pediatrics, 121(4), 1008-1015.

Kagan, S. L. \& Rigby, E. (2003). Policy Matters: Setting and Measuring Benchmarks for State Policies: Improving the Readiness of Children for School: Recommendations for State Policy. Washington, DC: Center for the Study of Social Policy.

Klemenović, J. (2009). Savremeni predškolski programi [Comtemprorary pre-school curricula]. Novi Sad: Savez pedagoških društava Vojvodine; Vršac: Visoka škola strukovnih stiudija za obrazovanje vaspitača.

Klemenović, J. (2014). Spremnost za školu u inkluzivnom kontekstu [School Readiness in the Inclusive Context]. Novi Sad: Filozofski fakultet.

Krnjaja, Ž., Pavlović Breneselović, D. (2013). Gde stanuje kvalitet (knjiga 1): politika građenja kvaliteta u predškolskom vapitanju [Where does Quality Live (Book 1): Policies of Building Early Childhood Education Quality]. Beograd: IPA.

Krstić, K. (2017). Moguća polazišta u kreiranju partnerstva porodice i predškolske ustanove [Possible Starting Points in Building a Partnership of Family and Preschoo Iinstitution]. U Ž. Milanović (ur.), Third international interdisciplinary conference for young scholars in social sciences and humanities Contexts (str. 541-557). Novi Sad: Filozofski fakultet, Univerzitet u Novom Sadu.

Krstić, K. i Zuković, S. (2017). Tranzicija u školu: značaj partnerstva porodice i vaspitnoobrazovnih institucija [The Transition to School: The Importance of Partnership Between the Family and Educational Institutions]. Nastava $i$ vaspitanje, 66(1), $143-156$.

Margetts. K. (2003). Planning Transition Programmes. In H. Fabian \& A. W. Dunlop (Eds.), Transitions in the Early Years: Debating Continuity and Progression for Young Children in Early Education (pp.111-122). London and New York: Taylor \& Francis Group.

Meisels, S. J. (1998). Assessing Readiness. Center for the Improvement of Early Reading Achievement, Ann Arbor. Retrieved April 12, 2016 from http://files.eric.ed.gov/ fulltext/ED429272.pdf

Mihić, I., Rajić, M., Mirosavljević, S., Stojić, O. i Lukovnjak, S. (2016). Kućne posete porodicama - primer dobre prakse u seoskom vrtiću [Home Visits to Families - An Example of Good Practice in Rural Kindergarten]. Pedagoška stvarnost, 62(3), 397-411.

Miškeljin, L. (2014). Difersifikacija - Značenja i politike u praksi predškolskog vaspitanja i obrazovanja u Srbiji [Diversification - Meanings and Policies in Practice of Preschool Education in Serbia]. U D. Pavlović Breneselović i Ž. Krnjaja (Prir.), Pedagoški modeli evaluacije $i$ strategije razvijanja kvaliteta obrazovanja (str. 35-49). Beograd: IPA.

Nenadić-Bilan, D. (2015). Društvena potpora roditeljima djece predškolske dobi [Social Support for Parents of Preschool Children]. Školski vjesnik, 64(1), 45-63.

Niesel, R. \& Griebel,W. (2007). Enhancing the competence of transition systems through co-construction. In A.W. Dunlop \& H. Fabian (Eds.). Informing Transitions in the Early Years: Research, Policy and Practice (pp.21-32). Open University Press.

Nissksaya, A. (2018). School Readiness Outcomes of Different Preschool Educational Approaches. Psychology in Russia: State of the Art, 11(1), 43-60. 
Oterkiil, C. \& Ertesvåg, S. (2012). Schools' Readiness and Capacity to Improve Matter. Education Inquiry, 3(1), 71-92. DOI: 10.3402/edui.v3i1.22014

Pavlović Breneselović, D. (2015). Gde stanuje kvalitet (knjiga 2): istraživanje sa decom prakse dečjeg vrtića [Where Does Quality Live (Book2): Research with Children the Practice of Kindergarten]. Beograd: IPA.

Pavlović Breneselović, D. i Krnjaja, Ž. (2017). Kaleidoskop: osnove diversifikovanih programa predškolskog vaspitanja i obrazovanja [Kaleidoscope: Manual for Diversification of Programs for Pre-school Education]. Beograd: IPA.

Pećnik, N. (2013). Kako roditelji i zajednice brinu o djeci najmlađe dobi u Hrvatskoj [How Parents and Communities Care for the Youngest Children in Croatia]. Zagreb: Ured UNICEF-a za Hrvatsku.

Pianta, R. (2002). School Readiness: A Focus on Children, Families, Communities, and Schools. The Informed Educator Series. Arlington, VA: Educational Research Service.

Polovina, N. (2009). Priprema roditelja za detetov polazak u školu [Preparing Parents for the Child's School Start]. Nastava i vaspitanje, 58(1), 91-103.

Pravilnik o opštim osnovama predškolskog programa, Službeni glasnik RS - Prosvetni glasnik, Br.14 (2006).

Pravilnik o opštim osnovama predškolskog programa, Službeni glasnik RS - Prosvetni glasnik, br.88/17 i 27/18 (2018).

Radojičić, V. i Rašković, I. (2006). Pokrenimo zajednice 3: priručnik sa primerima dobre prakse u građenju partnerstva $i$ prikupljanju sredstava u lokalnim zajednicama Srbije i Crne Gore [Let's Set Our Communites in Motion 3: Manual with Examples of Positive Praxis in Building Partnerships and Fundraising in Local Communities of Serbia and Montenegro]. Beograd: Balkanski fond za lokalne inicijative.

Redding, S. (1997). Parents and Learning. Educational Practices Series-2. Brussels (Belgium): International Academy of Education, Geneva (Switzerland): International Bureau of Education. Retrieved August 25, 2015 fromhttp://files. eric.ed.gov/fulltext/ED463858.pdf

Rhode Island KIDS COUNT (2005). Getting Ready: Findings from the National School Readiness Indicators Initiative: A 17 State Partnership. Retrieved March 2, 2016 from http://www.rikidscount.org/Portals/0/Uploads/ Documents/Early\%20Learning/Getting\%20Ready/Executive\%20Summary.pdf

Şahin, I. T., Sak, R. \& Tuncer, N. (2013). A Comparison of Preschool and First Grade Teachers' Views about School Readiness. Educational Sciences: Theory \& Practice, 13(3), 1708-1713. DOI: 10.12738/estp.2013.3.1665

Slunjski, E. (2006). Stvaranje predškolskog kurikuluma u vrtiću - organizaciji koja uči. Zagreb: Mali profesor; Visoka učiteljska škola u Čakovcu.

Shore, R. (1998). Ready Schools. A Report of the Goal 1 Ready Schools Resource Group. Washington, DC: National Education Goals Panel.

Taguma, M., Litjens, I. \& Makowiecki, K. (2013). Quality Matters in Early Childhood Education and Care: Sweden 2013. OECD. Retrieved January 5, 2019 from http://www.oecd.org/education/school/SWEDEN\%20policy\%20profile\%20-\% 20published\%2005-02-2013.pdf DOI: https://dx.doi.org/10.1787/978926417 6744-en

UNICEF (2012). School Readiness: a conceptual framework. New York: United Nations Children's Fund.

UNICEF (2014). Sreća i porodice sa decom u Srbiji: kako oblikovati javne politike za dobrobit porodica [Happiness and Families with Children in Serbia: How to Design Public Policies for the Well-Being of Families with Children]. Retrieved September 15, 2016 from http://www.unicef.org/serbia/18259_27037.html 
WEBIN (2015). Priručnik za lokalnu zajednicu: umrežavanje prema modelu usmerenom ka detetu [Handbook for Local Community: Networking According to ChildOriented Model]. Beograd: Agroinvest Fondacija Srbija.

Woodhead, M. \& Moss, P (2007). Early Childhood and Primary Education: Transitions in the Lives of Young Children. UK: The Open University.

Wynn, L. (2002). School Readiness: Starting Your Child Off Right. Raleigh: North Carolina Partnership for Children. Program Services Paper. Retrieved April 16, 2016 from http://files.eric.ed.gov/fulltext/ED472190.pdf

Zakon o osnovama sistema obrazovanja i vaspitanja, Službeni glasnik RS. Br. 88 (2017).

Zaslow, M., Calkins, J., Halle, T., Zaff, J. \& Geyelin, M. N. (2000). Background for Community-Level Work on School Readiness: A Review of Definitions, Assessments, and Investment Strategies. Final Report to the Knight Foundation. Washington, DC: Child Trends, Inc.

Zlatatović, V. i Mihajlović, M. (2013). Karika koja nedostaje: mehanizmi podrške detetu sa teškoćama pri prelasku na sledeći nivo obaveznog obrazovanja u „redovnom obrazovnom sistemu” [The Missing link: Support Mechanisms for the Child with Difficulties When it Comes to Move to the Next Level of Compulsory Education in "the Regular Education System"]. Beograd: Centar za interaktivnu pedagogiju.

Zuković, S. (2013). Partnerstvo porodice, škole i zajednice - teorijski i praktični aspekti [Family-School-Community Partnership - Theoretical and Practical Aspects]. Godišnjak Filozofskog fakulteta u Novom Sadu, 38(2), 55-68. DOI: http://dx.doi.org/10.19090/gff.2013.2.55-68

Zuković, S. (2017). Savetodavni rad u institucijama vaspitanja $i$ obrazovanja [Counseling in the Institutions of Education and Upbringing]. Novi Sad: Filozofski fakultet.

Zuković, S. \& Knežević-Florić, O. (2014). Pedagogical Management in the Function of Family and School Partnership. Školski vijesnik, 63(1-2), 201-212.

\title{
CHILDREN'S SCHOOL READINESS: THE IMPORTANCE OF READINESS AND THE INTERACTION IN THE MICROSYSTEMS OF THE DEVELOPMENT ENVIRONMENTS
}

\author{
Slađana Zuković ${ }^{1}$, Kristina Krstić ${ }^{2}$ \\ ${ }^{1}$ University of Novi Sad, Faculty of Philosophy, Novi Sad, Serbia \\ ${ }^{2}$ Academy of Professional Studies Šabac, Šabac, Serbia
}

\section{Summary}

When starting school, a child begins a new chapter in their development, where a new role of a child as a first-grade pupil goes through a wide range of different changes and demands in each respective manner. Bearing in mind, on the one hand, different individual characteristics of every child, and, on the other, new and different experiences when starting school, there is a tendency to re-examine the factors shaping (and influencing) the child's readiness for school. Starting from a brief retrospect of the approaches that review the phenomenon of school readiness, the essence of this paper consists of an interactive approach which, beside the importance of individual children's 
characteristics, also emphasizes the significance of conditions in the microsystem of the development environments in which the child spends their time, as well as their synergistic actions. In accordance with this viewpoint, the paper offers a retrospect on the aspects of children's school readiness, but also the aspects of the readiness of family, pre-school institution/school and community, as key environments which need to offer adequate stimuli for children's development in its entirety, and thus for their starting school. Apart from that, there is an emphasis on the importance of establishing partnership between family, educational institutions and community, since that relationship leads to the strengthening of the connection between children's experiences and learning in these environments. Considering the aspects of children's school readiness, it can be noted that children's school readiness covers five interconnected areas: physical and motor development; social and emotional development; approach to learning; communication skills and literacy development; cognitive development and general knowledge. Regarding the family context, the paper accentuates that the dimension of the "ready family" within the concept of children's school readiness purports supportive family surroundings, i.e. creating an adequate "family curriculum" and maximal parental involvement in creating daily activities which would prepare the child to successfully adapt to the school environment. Another extremely significant element in children's school readiness is the activity of organized educational institutions. Apart from the emphasis on the individual importance of the pre-school institution and school, along with the roles of the educator and teacher as the representatives of these environments, the significance of their cooperation and adjusted activity especially contributes to the continuity of educational influence. In this manner, there is undoubtedly the influence of protective factors in a community that is the availability of various physical, institutional and social resources within a community, which can greatly contribute to children's school readiness. Regarding that, there are prominent resources offered by formal, semi-formal and informal support systems on the local environment level, and the possibility of joint action of development environments through examples of good practice in our educational context. Although each of these mentioned microsystem environments individually contributes to children's school readiness, it can be concluded that the best effects are accomplished through their interaction which leads to the continuity of influence and the maximum of reaching children's potentials in new education environment. 